\title{
固体高分子形燃料電池
}

固体高分子形燃料電池には，一般に化学的安定性が炭化水素系ポリマーに比べてきわめて高いと言われてい るフッ素系イオン交換ポリマーが広く用いられているが，このフッ素系ポリマーでも条件によっては劣化が 起こる。本稿では, 燃料電池運転環境下でのフッ素系イオン交換ポリマーの劣化機構と, 最近開発された高 耐久性の膜・電極接合体 (MEA) について紹介する。

寺田一郎*・中川秀樹**

\section{Polymer Electrolyte Fuel Cell}

Ichiro TERADA* and Hideki NAKAGAWA**

Research Center* and New Business Development \& Promotion Center**

E-mail: ichiro-terada@agc.co.jp* and hideki-nakagawa@agc.co.jp**

Abstract: Perfluorosulfonic acid (PFSA) polymers have been extensively used for Polymer Electrolyte Fuel Cells (PEFCs) because it is generally said that they have considerably higher chemical stability over hydrocarbon-based polymers. However, PFSA polymers can be degraded under severe operating conditions such as high temperatures or low humidity conditions.

Degradation mechanism of PFSA polymers during fuel cell operation and the performance of the newly developed MEAs are presented.

Keywords: Fuel Cell/Polymer Electrolyte Membrane/Membrane Electrode Assembly/Fluoropolymer/Durability

\section{1.はじめに}

固体高分子形燃料電池 (PEFC) は, リン酸型燃料電池 (PAFC) や溶融炭酸塩型燃料電池 $(\mathrm{MCFC})$, 固体電解質型 燃料電池 (SOFC) などの燃料電池に比較して, 低温作動, 高出力密度などが特徴であり，住宅用コージェネレーショ ンシステムや自動車用電源, 携帯用小型電源など, 次世代 のエネルギー機器として期待が高まっており, 自動車メ一 カーや電気メーカー, パーツメーカーなどで盛んに研究が 行われている。

心臓部である燃料電池スタックの中には，イオン交換膜 之触媒電極層が積層された, 膜・電極接合体 (MEA) が装 填されており,この MEA の性能が燃料電池の特性を決定 することとなる。従来は温度 $70^{\circ} \mathrm{C}$ 以下で, かつ加湿度 100\%付近の湿度で運転されていたが，実用化に向かって， より高い温度, およびより低い加湿度で運転可能な MEA の要求があり, これらの要求に対して, 改良された MEA が種々提案されている。なかであイオン交換ポリマーの改 良は耐久性に大きく影響するため, 非常に重要であり, 新
規なフッ素系ポリマーや非フッ素系ポリマー，およびそれ らを用いた補強膜などの検討がなされている。

本稿では，固体高分子形燃料電池用の膜および MEA に 要求される特性をまとめるとともに, とくに水素/酸素型 燃料電池用膜・電極接合体についてのポリマー劣化挙動に 関して最近解析されてきている結果や，その結果を基に新 たに開発された膜・電極接合体の特性や耐久性についても 記述する。

\section{2. 固体高分子形燃料電池用膜・電極 接合体への要求特性}

固体高分子形燃料電池の作動原理図を図 1 に示す。一般 的にはイオン交換膜の両側に白金含有触媒とイオン交換樹 脂の混合物汃らなる触媒電極層, さらにその外側に多孔質 カーボン系材料からなるガス拡散層が積層され，アノード 側に水素, カソード側に空気または酸素を供給する。ア ノード側では，触媒の作用で水素がプロトンと電子に解離 し，プロトンはアノード触媒を被覆しているイオン交換樹
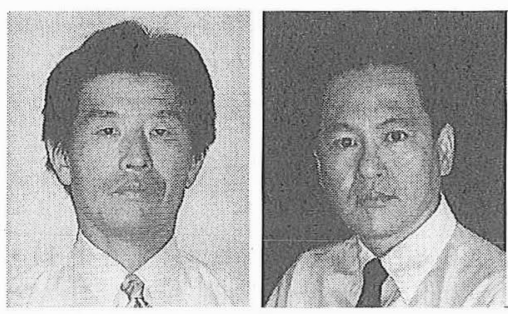

* (左)

旭硝子(株)中央研究所（221-8755 横浜市神奈川区羽沢町 1150 番地)・PEMFC プロジェク トリーダー, 工学博士. 1986年 九州大学大学院工学研究科応用化学専攻博士後期課程中退. 専門は分離膜, イオン交換膜.

** (右)

旭硝子(株)新事業推進セン夕ー（同上)・統括主幹. 1986年京都大学大学院工学研究科合成化 学専攻修士課程修了，専門は有機合成，有機光化学，ポリマーアロイ。 


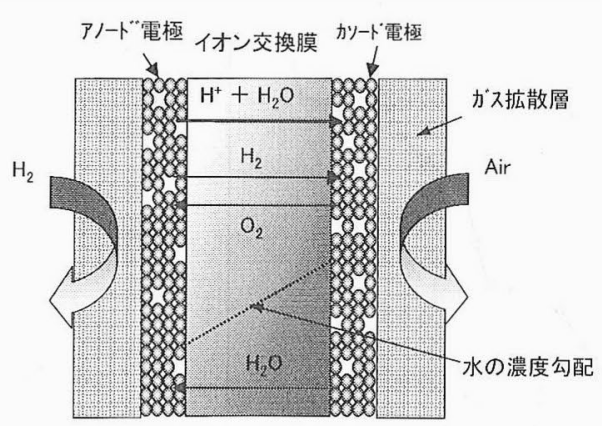

図 1 固体高分子形燃料電池の原理

表 1 燃料電池用 MEA の構成部材之要求特性.

\begin{tabular}{|c|c|}
\hline 構成部材 & 要求特性 \\
\hline 膜 & $\begin{array}{l}\text { 化学的安定性, 高プロトン導電性, ガス遮 } \\
\text { 断性, 高機械的強度, 高水移動性, 電極接 } \\
\text { 合性, ハンドリング性, 厚み均一性, 低コ } \\
\text { スト, 信頼性 }\end{array}$ \\
\hline 触媒電極層 & $\begin{array}{l}\text { 触媒高活性, 触媒金属溶出耐性, 触媒金属 } \\
\text { 粒径安定性, 触媒担体腐食而性, 被覆樹脂 } \\
\text { の高プロトン導電性, 被覆樹脂の化学的安 } \\
\text { 定性, 高ガス拡散性電極構造, 電極排水 } \\
\text { 性, 低コスト, 信頼性. }\end{array}$ \\
\hline ガス拡散層 & $\begin{array}{l}\text { 高ガス拡散性, 高導電性, 排水性, 厚み均 } \\
\text { 一性, 低コスト, 信頼性 }\end{array}$ \\
\hline $\begin{array}{l}\text { ガスケット・ } \\
\text { シール }\end{array}$ & $\begin{array}{l}\text { ガスシール性, 化学的安定性, 耐熱性, 耐 } \\
\text { クリープ性. }\end{array}$ \\
\hline
\end{tabular}

脂，イオン交換膜，カソード触媒を被覆しているイオン交 換樹脂と移動しカソード触媒表面へと到達する。一方, 電 子はカーボン材料㧍よび外部回路を介してカソード側へと 移動し, カソード触媒表面へ到達する。カソード触媒表面 では, これらのプロトンと電子, さらにカソード側で供給 される酸素が反応し水を生成する。このようにイオン交換 膜が存在することで水素の酸化と酸素の還元が別の場所で 起こり, 燃料があつ化学エネルギーを直接電気エネルギー に変換できる。

$\mathrm{H}_{2}+1 / 2 \mathrm{O}_{2} \rightarrow \mathrm{H}_{2} \mathrm{O}$ の反応では燃焼熱は, $25^{\circ} \mathrm{C}$ において $-285.8 \mathrm{~kJ} / \mathrm{mol}$ であり, 水素-酸素両極間の標準起電力が $1.229 \mathrm{~V}$ であることから, 取り出せる電気エネルギーを計

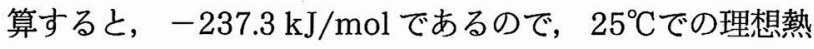
効率は約 83\%ということになる。しかしながら，実際には 膜抵抗や電極の抵抗，接触抵抗などの抵抗損，電極での活 性化過電圧, 原料ガスの濃度分極加ら生じる濃度過電圧の 影響でこれより小さいあのとなる。そこで，これらの抵抗 損や過電圧をできるだけ少なくして，高効率でエネルギー を取り出すことが必要とされる。また, 燃料電池運転環境 下では $\mathrm{OH}$ ラジカルが発生するため, 安定的な性能発現の ためには化学的安定性に優れた素材が求められる。

表 1 亿燃料電池用 MEA の構成部材と, それらに要求さ れる特性をまとめた。これらの特性の中であっとも重要な 特性は, 膜の化学的安定性であり, 一般的に化学的安定性 が高いと言われているパーフルオロスルホン酸系ポリマー

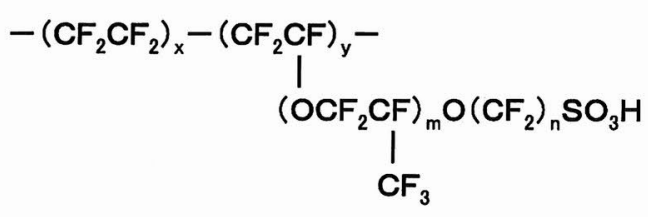

図 2 パーフルオロスルホン酸ポリマーの化学構造

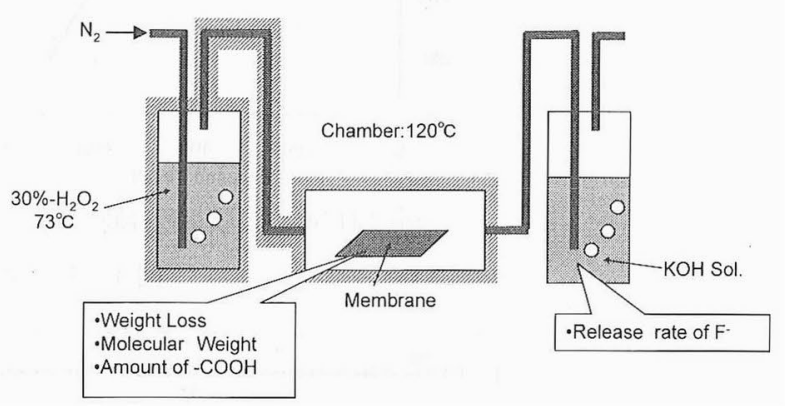

図 3 ポリマー分解劣化機構解明のための新規試験法

が従来用いられてきたが，このパーフルオロスルホン酸系 ポリマーでさえも, $90^{\circ} \mathrm{C}$ 以上の高温条件や低加湿の条件で は分解が起こり, 短時間でアノード側からカソード側への 水素リークが増大したり, 発電特性が低下するという問題 が発生する。この原因としては, 機械的要因と化学的要因 が考えられるが，抒もには化学的要因の影響が大きく，力 ソードまたはアノード中の触媒白金上で水素之酸素が反応 し過酸化水素を発生させ， その過酸化水素加ら生成するラ ジカルがポリマーを攻撃して分解が起こると言われてい る。そこで, このパーフルオロスルホン酸ポリマーの劣化 機構に着目し, 解析を行った。

\section{3. パーフルオロスルホン酸ポリマーの 劣化機構解明検討}

パーフルオロスルホン酸ポリマーの化学構造を図 2 に 亦す。このパーフルオロスルホン酸ポリマーを使用した MEA の耐久性は，一般的な炭化水素系ポリマーと比較す ると優れるが，パーフルオロスルホン酸ポリマーといえど あ従来のポリマーではラジカルの攻撃による分解劣化が進 行し，低加湿や高温の運転条件では十分な耐久性が確保で きなかった1)。この分解劣化機構を解明するため，実際の 燃料電池の運転環境を模擬した試験法を考案し, 解析を 行った 2 。図 3 に試験法の概略図を示す。通常行われる OCV 試験やフェントン試験とは異なり，ガス状の過酸化 水素に膜を暴露する試験手法であり, 劣化後のポリマーの 解析が容易であることが特徴である。

この試験法を用いて，旭硝子製の従来のパーフルオロス ルホン酸膜（SH-50 膜）について検討を行った。その結果 を図 4 に示す。膜重量は経時的に急激に減少し, 対応して Fイオン排出速度が上昇した。Fイオン排出速度について は, 図 3 に示すように $\mathrm{KOH}$ 水溶液でトラップし, その水 溶液中の F イオン濃度をイオンクロマトグラフィーで測 


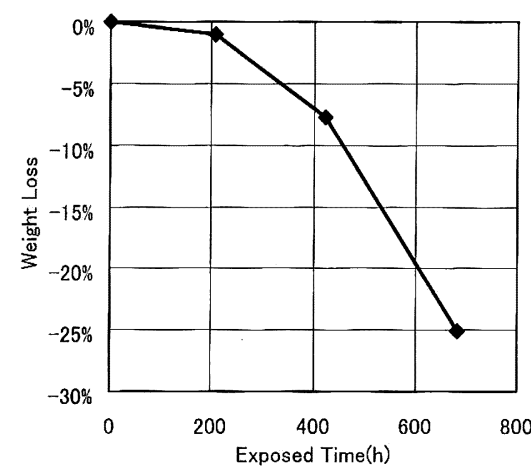

(a) SH-50 膜の膜重量経時変化

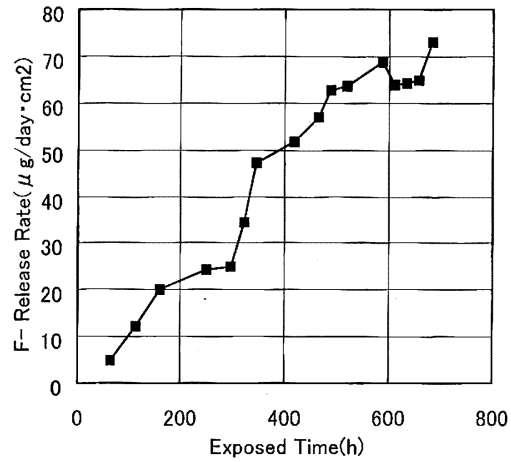

(b) Fイオン排出速度の経時変化

図 4 ポリマー分解劣化試験結果

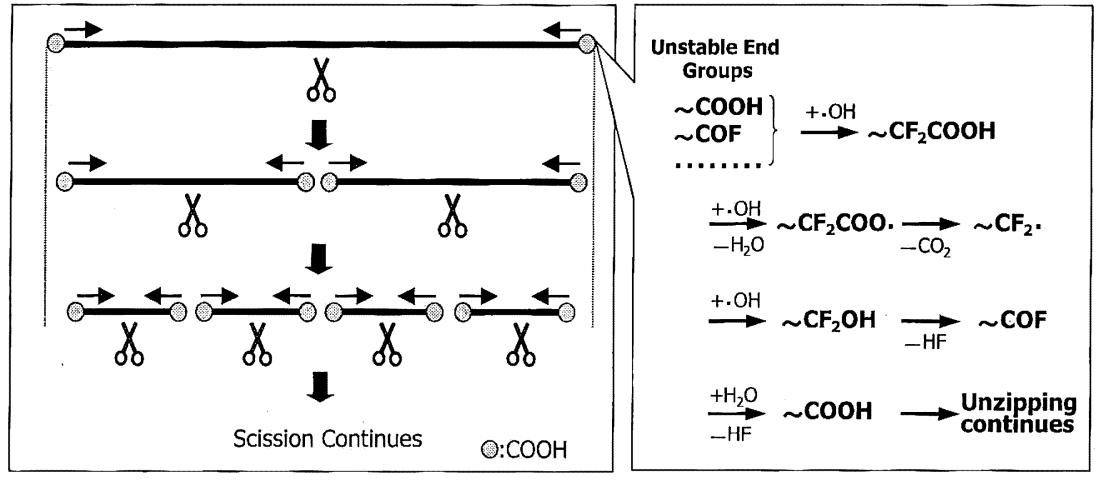

図 5 パーフルオロスルホン酸ポリマーの推定分解機構

定して求めた。劣化後の膜の分子量分布を測定したとこ 万，過酸化水素ガスに対する暴露時間とともに分子量は急 激に低下しており，主鎖切断が起きているものと考えら れ，約 700 時間で，数平均分子量が $1 / 20$ に低下した。以 上の結果から推定される分解機構を図 5 に示した。分解劣 化機構としては，これまではポリマーの不安定末端から起 こるということが提案されていたが3)，それだけではなく， 主鎖からも起こっていることが明らかとなった。Delaney ら)む $\mathrm{FeSO}_{4}$ を含浸した膜を過酸化水素蒸気にさらす気 相フェントン試験と通常の液相フェントン試験で比較した 検討を行い，ポリマー分解機構としては，末端加らのあの と主鎖で起こる二つのモードがあることを確認している。

\section{4. ポリマー分解劣化対策検討と MEA の 安定性向上検討}

上記の分解劣化機構を基に，各種の改良された膜および MEA が検討されている。以前はポリマーの分解少化はポ リマー末端で起こると言われていたため，改良検討はおす にポリマー末端のフッ素化処理であったが，最近はフッ素 化処理だけでなく，ポリマーの化学構造の検討や MEA の 構造検討, 膜補強体の検討, 添加剤による劣化防止検討な ぞが行われている。

岩田ら5は補強材を用いた物理的補強構造を導入し，か つ化学的安定性を高めた電解質ポリマーを使用した膜を作

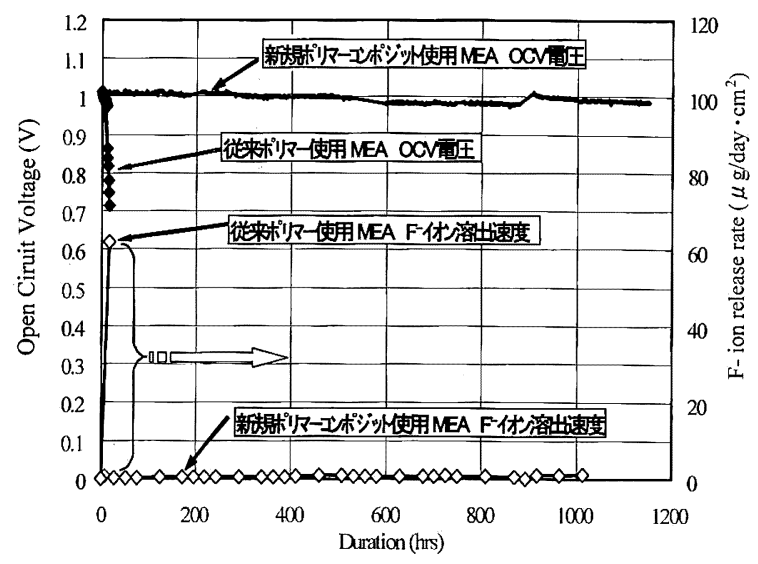

図 $6 \mathrm{NPC}$ を用いた MEA の $120^{\circ} \mathrm{C}, 18 \% \mathrm{RH}$ での開回路耐 久試験

製し，分解劣化の指標であるフッ素イオン溶出速度が $1 / 5$ に抑制されることを明らかにしており，また丸山ら6)す類 似の検討で而久性が大幅に改善された膜を作製している。 三宅ら7は化学的安定性を高めた新規な複合膜を作製し， $100^{\circ} \mathrm{C}$ での ON-OFF 耐久試験で 3,000 時間を超える耐久

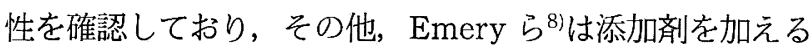
ことで膜の化学的耐久性が改善されることを明らかにして いる。

筆者らは従来とは異なる化学構造をすつ新規なポリマー コンポジット (NPC) を開発し MEA を作製して，その耐久 性の評価を行った9), 10)。耐久性の評価方法としては，通常 の固体高分子形燃料電池運転条件である温度 $60 \sim 80^{\circ} \mathrm{C}$, 


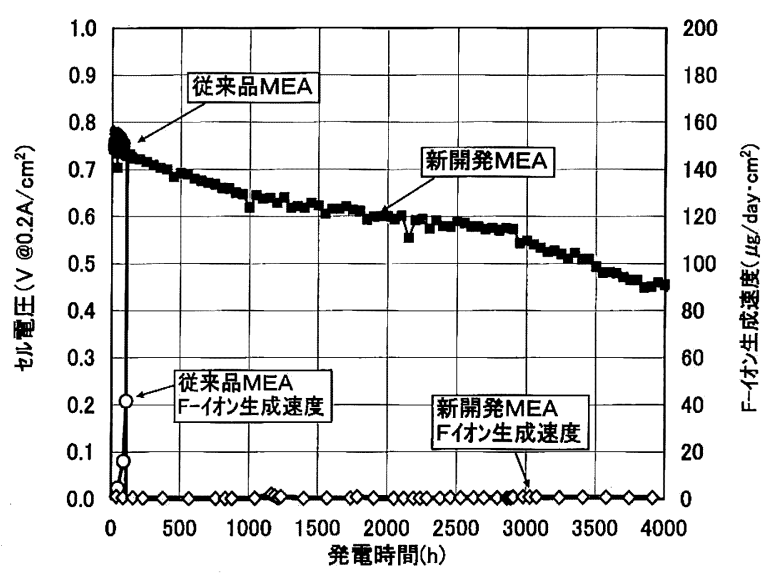

図 7 NPC を用いた MEA の $120^{\circ} \mathrm{C}, 50 \% \mathrm{RH}$ での定電流密 度連続発電耐久試験

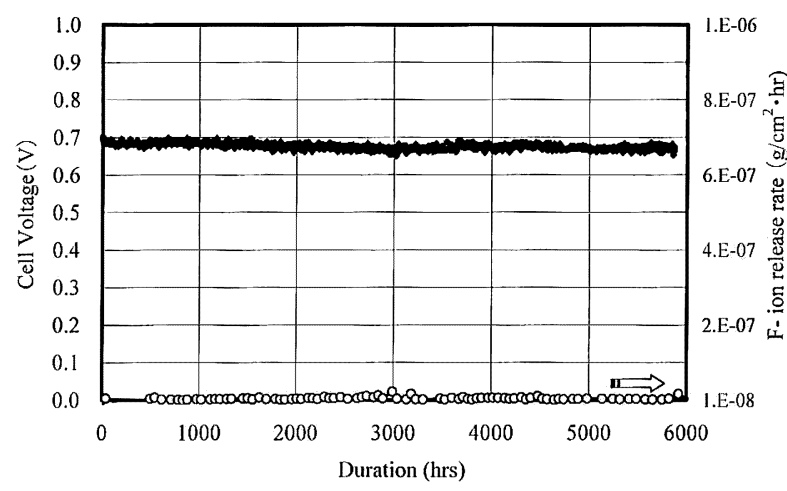

図 8 改良触媒を用いた NPC 系 MEA の $120^{\circ} \mathrm{C}, 50 \% \mathrm{RH}$ で の連続発電試験

相対湿度 $80 \sim 100 \%$ と比較して，より撖しい条件である $120^{\circ} \mathrm{C}$, 相対湿度 $18 \%$ を選択し，かつ電位が高くてカソー ドでの水生成がない開回路運転で行った。図 6 にその結果 を示す。従来のパーフルオロスルホン酸ポリマーを用いた MEA の場合には約 10〜20 時間でポリマー分解が激しく 進行し，それ以上の運転が不可能であったが，NPCを使用 した MEA では 1,000 時間以上の運転が可能で, 開回路電 圧むほぼ一定に保持された。

図 7 には, $120^{\circ} \mathrm{C}$, 相対湿度 $50 \%$ $0.2 \mathrm{~A} / \mathrm{cm}^{2}$ の定電流 密度発電連続試験を行った結果を示す。従来のポリマーで は 100 時間程度で運転が不可能となったが, 新規ポリマー コンポジット系では 4,000 時間の運転が可能であった。し かしながら，このMEA は発電時間とともに電圧が低下 し, 電圧低下率は約 $75 \mu \mathrm{V} / \mathrm{h}$ と大きいむのであった。そこ でこの電圧低下の原因を究明するため, MEA を分析した ところ, 膜は劣化している様子がなかったが，カソード電 極の厚みが約 $1 / 3$ まで減少して扔り，とくにカソード触媒 の担体カーボンが消失していることが明らかとなった。 MEA の安定性向上のためには, 高分子電解質膜の化学的 安定性だけでなく, 触媒電極層の化学的安定性む要求され る。今回の場合は, カソード触媒の担体が腐食を起こして
いることが明らかであったため，とくにカソード触媒の担 体として耐久性が高いと思われる開発品触媒を用いて検討 を行った。その結果を図 8 に示す。種々の検討の結果，力 ソード $\mathrm{Pt}$ 量を $0.2 \mathrm{mg} / \mathrm{cm}^{2}$ 之従来の $1 / 3$ に低下させたに あかか力わず，特性は比較的良好で 5,000 時間以上の運転 が可能であり, また電圧低下率む小さく, 安定性の向上し たMEA となっていることがわかった。

\section{5. ま と め}

燃料電池用フッ素系電解質膜抢よび MEA に関しての最 近の進歩について記載した。電解質ポリマーに関しては, 化学的耐久性を向上させるための各種の検討がなされてお り, 燃料電池スタックの耐久性は大幅に改善されつつあ る。筆者らが検討している新規ポリマーコンポジット (NPC) を用いる系でも，化学的安定性が飛躍的に向上する ことが明らかとなった。また，MEAの安定性に関しては， 電解質膜だけでなく触媒電極層の化学的安定性も非常に重 要であり, 触媒担体の改良む MEA の安定性向上に寄与す ることを示した。今後は燃料電池用 MEA に対する要求と 期待はますます高いものとなり，実用試験に耐え，かつ品 質とコストに優れるあのが求められると考えられ，それら の要求に耐えうる開発していきたいと考えている。

\section{文献}

1) E. Endoh, S. Honmura, S, Terazono, H. Widjaja, Y. Takimoto: Abstract 1884, The $206^{\text {th }}$ Meeting Abstracts of the Electrochemical Society (2004)

2) S. Honmura, K. Kawahara, T. Shimohira: 2005 Fuel Cell Seminar Abstracts, No. 103 (2005)

3) D. E. Curtin, R. D. Losenberg, T. J. Henry, P. C. Tangeman, M. E. Tisack: J. Power Sources, 131, 41 (2004)

4) W. E. Delaney, W. Liu: ECS Transactions, 11(1), 1093 (2007)

5）岩田 良, 角田勝治, 本松 誠, 賀来群雄, G. Escobedo, R. L. Perry, A. DiAndreth: 第 14 回燃料電池シンポジウム予稿 集, p. 32 (2007)

6) 丸山将史, 坂本 敦, 石川雅彦, 鈴木健之, 難波隆文：第 14 回燃料電池シンポジゥム予稿集, p. 35 (2007)

7) 三宅直人：NEDO シンポジウム 固体高分子形燃料電池の高 性能化・高耐久化への展望と今後の技術開発の重点課題予稿 集, p. 63 (2008).

8) M. Emery, M. Frey, M. Guerra, G. Haugen, K. Hintzer, K. H. Lochhaas, P. Pham, D. Pierpont, M. Schaberg, A. Thaler, M. Yandrasits, S. Hamrock: ECS Transactions, 11(1), 3 (2007)

9) E. Endoh, H. Kawazoe: Abstract 763 , The $207^{\text {th }}$ Meeting Abstracts of the Electrochemical Society (2005)

10) E. Endoh, H. Kawazoe, H. Nakagawa: Abstract 1187, The $208^{\text {th }}$ Meeting Abstracts of the Electrochemical Society (2005) 